\title{
Molecular cloning and expression patterns of the Vasa gene from Rana nigromaculata (Amphibia: Anura)
}

\author{
Rui Jia '; Liu-Wang Nie ${ }^{1,2}$; Ning Wang ${ }^{1} \&$ Jingjing Wang ${ }^{1}$ \\ ${ }^{1}$ College of Life Sciences, Anhui Normal University. 1 East Beijing Road, Wuhu, Anhui, 241000, China. \\ E-mail: jiarui20021104@yahoo.com.cn; \\ ${ }^{2}$ Corresponding author. E-mail: Iwnie@mail.ahnu.edu.cn
}

\begin{abstract}
The Vasa protein is a member of the DEAD (Asp-Glu-Alu-Asp) box family of ATP-dependent RNA helicases. The Vasa gene is specifically expressed in germ-line cells of many metazoans and is known to play a critical role in gametogenesis and reproductive regulation. In this paper, we isolate the full length cDNA sequence of the Vasa gene from the frog Rana nigromaculata Hallowell, 1861. The open reading frame (ORF) encoding 398 amino acid residues has nine conserved motifs. According to the similarities at the amino acid sequenceÿthe phylogenetic analysis of Vasa gene was consistent with the evolution relationships from chordates to mammals. Furthermore, the expression pattern analysis of RnVasa mRNA, using the technique of Reverse Transcriptase-Polymerase Chain Reaction (RT-PCR), showed a high level of transcripts in testis, ovary and kidney, whereas little to no signal was detected in other tissues, which suggests that it may play a role during gametogenesis.
\end{abstract}

KEYWORDS. DEAD-box; phylogenetic analysis; RT-PCR.

The Vasa gene encodes an ATP-dependent RNA helicase that belongs to the DEAD-box (Asp-Glu-Ala-Asp) protein family (Mochizuki et al. 2001), and is specifically expressed in the germ cell lineage of vertebrates (CASTRILLON et al. 2000, TsuneKAWA et al. 2000), insects (NAKaO 1999, Chang et al. 2002), ascidians (Fujimura \& Takamura. 2000), oysters (Fabious et al. 2004), brachiopods (SAGAWA et al. 2005), nematodes (KuZNicKi et al. 2000), planarians (Mochizuki et al. 2001), and cnidarians (MochizUKi et al. 2001). In Drosophila Meigen, 1830, after the Vasa gene expression was shown to be essential for polar granule formation and germ cell development (Liang et al. 1994), it has been broadly used as a germ cell marker for the germline cells in a variety of organisms.

RNA helicases are enzymes that catalyze the unwinding or separation of double-stranded RNA (dsRNA) by utilizing energy derived from hydrolysis of NTP (generally ATP) (HuANG \& Liu 2002). In addition, recent studies also suggested that some members might be involved in dissociation of protein-RNA interactions and modulation of other RNA secondary or tertiary structures (Rossler et al. 2001). Besides Vasa, some other RNA helicases, such as $p 68$ (HuANG \& Liu 2002), P72 (LAMm et al. 1996), Abstrakt (SCHMUCKER et al. 2000), etc.have different cellular locations and biological functions. RNA helicases are present in organisms ranging from $E$. coli to human and many viruses. RNA helicases are also involved in almost every cellular process of RNA metabolism including transcription, pre-mRNA splicing, rRNA processing, mRNA transport, translation initiation, ribosomal biogenesis and RNA decay during cell develop- ment and differentiation, exhibiting RNA helicase activity (Liang et al. 1994). The majority of RNA helicases have at least nine highly conserved motifs including a DEAD sequence. The large "DEAD-box" proteins family comprises several subclasses (including DEAD, DEAH and DExH groups) and all the members are generally believed to have both ATPase and RNA/DNA helicase activities (HuANG \& LiU 2002).

Vasa is required for the formation of germ cells and abdominal segments in the fruit fly (JOHNSTONE \& LASKO 2004). Vasa is also required for the embryonic stem cells differentiating into primordial germ cells and spermatogonium stem cells (GEIJEN et al. 2004, Hubner et al. 2003) and as a molecular marker for the diagnosis of male infertility (Guo et al. 2007). Vasa is not only required for spermatogenesis, but also for the embryonic stem cells differentiating into primordial germ cells (HUBNER et al. 2003). It may also play a role during gamete formation, for different splice variants have been identified with different expression patterns during male and female gonad differentiation in zebrafish (Krovel \& Olsen 2004). During male gametogenesis, mouse Vasa knockouts affect proliferation and differentiation of the premeiotic germ cells, and no sperm are formed in the developing gonad (TANAKa et al. 2000). In frogs, XVLG1 (Xenopus Vasa-like gene 1) protein was reported to function not only in germline cells but also in somatic cells (IKENISHI \& TANAKA 2000).

The widespread dark-spotted frog, Rana nigromaculata Hallowell, 1861, is a representative of Ranidae, Anura, Amphibia (CHEN et al. 1991), and plays an important role in the ecological 
balance of nature. Amphibians represent a bridge in the evolution of vertebrates from aquatic to terrestrial. They have highly specialized morphological and functional characteristics to adapt to different environments (Fei et al. 1999). The molecular mechanism of their reproductive biology, such as spermiogenesis and sex determination, have not been well investigated in this group. In our study, we used $R$. nigromaculata as the study object, isolated and cloned the full length of RnVasa cDNA, discussed its phylogenetic evolution and elucidated the expression pattern in various tissues, including gonads, by RT-PCR technique.

\section{MATERIAL AND METHODS}

\section{Animals}

Three male and six female adult dark-spotted frogs were obtained from Wuhu, Anhui, China. Various tissues including testicle, ovary, brain, kidney, liver, spleen, heart, and muscle were dissected from the adult frogs, immediately dipped in liquid nitrogen, and stored at $-80^{\circ} \mathrm{C}$ until used for total RNA isolation.

\section{RNA preparation and reverse transcription}

Total RNA was isolated from the testis of two adult frogs of $R$. nigromaculata according to the protocol of Trizol ${ }^{\circledR}$ Reagent (Takara, USA) and DNase digestion was completed during RNA purification using the RNase Free DNase Set (Takara, USA) according to the manufacturer's instructions. Total RNA integrity was checked by gel electrophoresis and purity established by calculating the ratio of the absorbance readings at $260 \mathrm{~nm}$ and $280 \mathrm{~nm}$. Total RNA $(1 \mu \mathrm{g})$ was reverse transcribed using 100 U of SuperScripti III Reverse Transcriptase (Invitrogen, USA) and $50 \mathrm{ng}$ of random hexamer primers (Invitrogen, USA) in a 25- $\mu$ l reaction according to the manufacturer's instructions. RNA samples were tested for genomic DNA contamination by including no enzyme reverse transcription (RT) and for reagent and aerosol contamination by including two no-template controls (one closed lid tube and one open lid tube during template addition).

\section{Isolation of Vasa from R. nigromaculata}

Degenerate polymerase chain reaction

According to Mochizuki et al. (2001), degenerate sense and antisense primers (Tab. I) were designed and synthesized according to a nucleotide alignment of conservative motifs of Vasa from related species that could be obtained from the National Center Biotechnology Information (NCBI) website. One $\mu \mathrm{l}$ of cDNA (equivalent to $40 \mathrm{ng}$ of total RNA) was amplified using $1 \mathrm{U}$ of Taq DNA polymerase (MBI, Fermentas, USA) and the degenerate primers described in table I at a $1 \mu \mathrm{M}$ final primer concentration, in a $20-\mu \mathrm{l}$ reaction with $64^{\circ} \mathrm{C}$ as the annealing temperature according to FuJIMURA \& TAKAMURA (2000) and PCR products were analyzed on a $2 \%$ agarose gel containing $0.5 \mu \mathrm{g} /$ $\mu \lambda$ of ethidium bromide and visualized under ultraviolet illumination. Gel bands of the correct estimated size were extracted using a Gel purification Kit (Sangon Inc, China).
Table I Primers for PCR amplification and analysis.

\begin{tabular}{ll}
\hline \multicolumn{1}{c}{ Primers } & \multicolumn{1}{c}{ Sequence $\left(5^{\prime}\right.$ - $\left.^{\prime}\right)$} \\
\hline Sense & ATGGCNTG(C/T)GCNCA(A/G)ACNG \\
Antisense & TATTGCCACAGCGTCCAGT \\
M13.F & TTGTAAAACGACGGCCAGTG \\
G13.R & CACACAGGAAACAGCTATGACCATG \\
GSP. R & ACGTTCTGAACAAGGTCCA \\
UTR. F & CAACCTCTTCAAGCCAAGC \\
UTR R & GATTGACGATAATCGTAGGC \\
EVASF & TGGCTTTGGCTGTCCGTAT \\
EVASR & CAACAGATAGGTAGTGAACG \\
ACtin5 & TATTGCCACAGCGTCCAGT \\
Actin3 & GGGAGTGATGGTTGGCATGG \\
\hline
\end{tabular}

\section{Cloning, sequencing, and analysis of data}

Extracted products were cloned into pGEM ${ }^{\circledR} \mathrm{T}$ Easy Vector System (Promega, USA) and sequenced using an ABI 377 sequencer (using M13.F and M13.R primers; Tab. I). The software Sequencher version 4.2 (Gene Codes Corporation) was used for sequence analysis. Analyzed sequences were compared to the GenBank database by BLASTN analysis (http://www.ncbi. nlm.nih.gov/blast).

\section{5'-and 3'-rapid amplification of CDNA ends (RACE)}

According to Frohman et al. (1988), 5'- and 3'-ends of cDNA were elongated. The sequence that had similarity greater than $80 \%$ to Vasa (i.e., Rana lessonae Vasa and Xenopus Vasalike gene (GenBank accession nos. Q3MSQ8 and Q91372, respectively) was used to design gene specific primers (GSP.F and GSP.R; Tab. I) for use in RACE experiments. The SMART ${ }^{\mathrm{TM}} \mathrm{RACE}$ cDNA Amplification Kit (Takara, USA) was used to isolate a full length Vasa-like cDNA by performing 5'- and 3'-RACE. A total of $1 \mu \mathrm{g}$ testis RNA was reverse transcribed for each of the $5^{\prime}$ and 3' reactions. RACE products were analyzed by gel electrophoresis, extracted, cloned, and sequenced as described above. The full-length open reading frame (ORF) of the $R$. nigromaculata Vasa homologue, RnVasa, was confirmed by designing primers in the untranslated regions (UTR) (UTR.F and UTR.R; Tab. I) and amplifying a continuous product. This product was visualized, extracted, cloned, and sequenced using the same procedures.

\section{Comparative sequence analysis}

The Entrez was performed iteratively at NCBI to search all full length Vasa protein sequences. Eight Vasa proteins from different evolutionary order species, including vertebrates and invertebrates, were selected to study their alignment with the deduced RnVasa sequence with Clustal W (Version2.0) multiple alignment s program (THompson et al. 1994). 


\section{Phylogenetic analysis}

Following alignment, a bootstrap neighbor-joining (NJ) tree (SAitou \& Nei 1987) was produced in Mega 3.1 (Kumar et al. 2004). The proteins used in the analysis are typical members of DEAD-box family proteins including Vasa in vertebrates and invertebrates: HsVasa; Homo sapiens Linnaeus, 1758 (BC088362), MoDVH: Mus musculus Linnaeus, 1758 (NM_010029), RnVLG: Rattus norvegicus (Berkenhout, 1769) (NM_001077647), GgVasa: Gallus gallus (Linnaeus, 1758) (NM_204708), RlVasa: Rana lessonae Camerano, 1882 (Q3MSQ8), XlVLG: Xenopus laevis Daudin, 1802 (Q91372), XtVasa: Xenopus tropicalis (Gray, 1864) (CAJ82187), OmVas: Oncorhynchus mykiss (Walbaum, 1792) (AB032566), ZfVLG: Danio rerio (Hamilton, 1822) (Y12007), CIDEAD1a: Ciona intestinalis (Linnaeus, 1767) (NM_001032421), Olvas: Oryzias latipes (Temminck and Schlegel, 1846) (NM_001104676), BmVLG: Bombyx mori Linnaeus, 1758 (NM_001043882), DmVasa: Drosophila melanogaster Meigen, 1830 (AAM49782), CgVLG: Crassostrea gigas (Thunberg, 1793) (AAR37337), TtuVas: Tubifex tubifex (Mueller, 1774) (AB205013), LvVLG: Litopenaeus vannamei (Boone, 1931) (DQ095772), TcVas: Tribolium castaneum (Herbst, 1797) (NM_001039431), AaVLG: Aedes aegypti Linnaeus, 1762 (AAY41941), CeGLH1: Caenorhabditis elegans Maupas, 1900 (XP_001301342), CeGLH2: C. elegans (EAX88412), MoPL10: M. musculus (NP_149068), XlAn3: X. laevis (NP_001095245), Hsp68: H. sapiens (AAB53236), Xlp68: X. laevis (AAH82849), ZfPL10: D. rerio (AAH59794), Mjpl10: Marsupenaeus japonicus (Bate, 1888) (ABC88642), MoeIF4A: M. musculus (P60843).

\section{Reverse transcription-polymerase chain reaction analysis (RT-PCR)}

To make single-stranded cDNA, $2 \mu \mathrm{g}$ total RNA from each tissue of testis, ovary, brain, kidney, liver, spleen, heart and muscle was transcribed to 1 st strand cDNA respectively by using SuperScriptTM III reverse transcriptase (Invitrogen,USA) with oligo $(\mathrm{dT})_{20}$ primer in a reaction volume of $20 \mu \mathrm{l}$. RT-PCR reaction conditions were as follows: $94^{\circ} \mathrm{C}, 4 \mathrm{~min}$; 35 cycles of $95^{\circ} \mathrm{C}, 40 \mathrm{~s} ; 56.5^{\circ} \mathrm{C}, 50 \mathrm{~s} ; 72^{\circ} \mathrm{C}, 60 \mathrm{~s}$; and $72^{\circ} \mathrm{C}$ for $10 \mathrm{~min}$. For RT-PCR amplification, we used $1 \mu \mathrm{l}$ of cDNA per reaction and $0.2 \mu \mathrm{M}$ primer sets of Evasa. In order to adjust for variations in the amount of input cDNA, the housekeeping gene $\beta$-actin was used as an internal standard (Tab. I). Each PCR product was detected by electrophoresis on $1.2 \%$ agarose gel.

\section{RESULTS}

\section{Cloning and molecular characterization of RnVasa}

Blackspotted frog full length RnVasa cDNA (2,175 bp, Accession no. EU035615, sequence not shown) was isolated from the testis. First, a 918-bp fragment was obtained by degenerated PCR. It was located in the middle of the open reading frame (ORF). Then, by using RACE PCR, a 5' region of 974 bp and a 3' region of 822 bp were isolated. RnVasa cDNA is composed of 1,197 bp, including an ATG start site that predicts an ORF encoding a protein of 398 amino acids. It has a 602 bp of 5'-untranslated region (UTR) and a 358 bp 3'untranslated region (UTR), including a typical polyadenylation signal sequence AATAAA located $34 \mathrm{bp}$ upstream from the poly (A) tail. Comparison of nucleotide sequence of RnVasa with those of other vertebrates indicates that the $R$. nigromaculata sequence is very similar to other anurans: $94 \%$ identity to $R$. lessonae (Rana) and $84 \%$ to X. laevis (Xenopus). The deduced amino acid sequence shows $68 \%$ of identity to zebrafish, $67 \%$ to chicken and $64 \%$ to mouse or human indicating that the Vasa gene is conserved through the process of evolution.

The RnVasa shows a high similarity to other Vasa proteins at two-thirds of its C-terminal protein (Fig. 1, shaded). It contains all nine conserved characteristic motifs, similar to the other DEAD-box proteins. Eight of the nine motifs are absolutely conserved including the four important ones (motifs I, II, III, and IV).

The nine characteristic motifs of Vasa proteins are as follows: AQTGSGKTAA (I), PTRELAVQ (Ia1), GG (Ia2), TPGR (Ib), DEAD (II), SAT (III), HGD (IV), ARGLD (V), HRIGRTGR (VI). The variable residues in the motif of Ia 1 are indicated by a frame (Fig. 1). Due to these characteristic motifs always present in DEAD-box proteins and now found in the deduced Vasa sequence, Vasa can be inferred to encode a putative RNA helicase of DEAD-box family. And the analysis also shows that the conserved motifs structure is almost the same as in vertebrates and invertebrates, suggesting strong conservation of the gene structure of Vasa during evolution.

\section{Phylogenetic analysis}

As shown in figure 2, the chosen members fell into several subgroups, such as the Vasa subgroup, p68 subgroup and PL10 subgroup, GLH subgroup,etc. Generally, the proteins of the same type cluster together, even if they belong to different species, such as Vasa subgroup, PL10 subgroup and GLH subgroup, whereas those of different types are not always close to each other, even from the same species, i.e. there is such a long distance between Vasa and p68 from $X$. laevis. Within a clade, DEAD-box proteins from closely related species often cluster, i.e. Vasas from amphibians cluster together, whereas those from distant species are often far away from each other, as in the case of Vasa from humans being distant from Vasa from silkworm. In addition, even though they are all found in amphibians, Vasa from $R$. nigromaculata is closer phylogenetically to that of its closely related species, $R$. lessonae, than to that of other frog species, $X$. tropicalis and X. laevis, as expected. The phylogenetic tree using the unweighted pair-group method using arithmetic averages (UPGMA) method also shows an identical branching pattern (not shown). But the topology and branch distances within each clade are not in good agreement with their expected evolutionary relationships, perhaps due to the structural divergence and functional complexity of DEADbox proteins within each subfamily. 


H. sapiens
G. gallus
R. nigromaculata
D. rerio
C. intestinalis
D. virilis
T. tubifex
H. magnipapillata

H. sapiens G. gallus R. nigromaculata D. rerio C. intestinalis D. virilis T. tubifex H. magnipapillata

DAPPA I LTFEEANLCQTLNNNIAKAGYTKLTPVQKYS I P I I LAGRDLMACAQTGSGKTAAF DPPAPLLAFEEANFAQTLRKNISKTGYSKLTPVQKHSIPVIQAGRDLMSCAQTGSGKTAAF

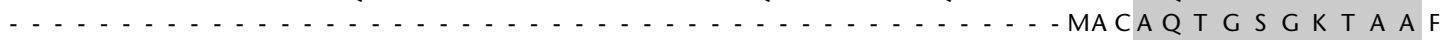
NPPKA IMTFEEAGLCDSLSKNVSKSGYVKPTPVQKHGIPI I SAGRDLMACAQT GSGKTAAF NAPKC I STFEMANLQET I LVNVQKAGYDRPTPVQKYS I P I INADRDLMACAQTGS GKTAA F NVPQP I KNFESARLRGIVLDNVVKSGYVVPTPIQKVSIPVIAEGRDLMACAQTGSGK TAA F

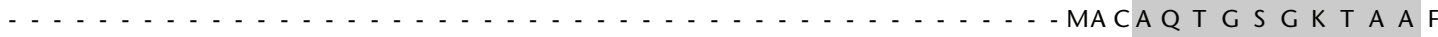
I I PSA I REFAEAN I DRT I LENVEKAHY I KPTPVQKYA I P I I TGNRDLMSCAQT GS GKTAAF

la1

LLP I LA HMMHDG I TA SRFKELQEPECI I VA PTRELVNQIYLEARKFSFGTCVRAVVIYGG LLP IVDRMMKDGVTAS - FPKQQDPQC I IVAPTRELINQIFLEARKFVYGTCIR PVVIVGG LLP I LAHLMVKGVQS SAFQTLKEPEA I IVAPTRELINQIYLDARKFAYGTCAR P V I Y G G LLP I LQR FMTDGVAA SKFSEIQEPEA I IVAPTRELINQIYLEARKFAYGTCVR PVVVYGG LLPVLTKLVESGVKSSEFSEKKTPQA I I I GPTRELVNQIFLEARKFSRST I I HPVVVYGC LLP I LNNILDE - - - SHDLE IGKPQAVIVSPTRELAIQIFNEARKFSYTTYLKIS IVYGC LLPVLTGMLRNGVEGGQFSVVQEPQA I IVGPTRELVTQIYNEARKFAHNTMVR PVVVYGG

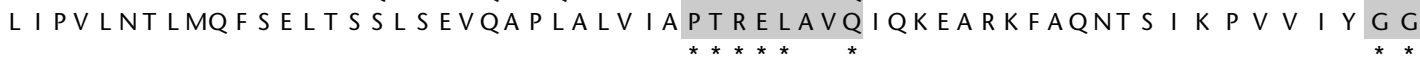

$\mathrm{Ib}$

II

TQLGHS IRQ IVQGCN ILCATPGRLMD I I GKEK IGLKQIKYLVLDEADRMLDMGF G P M K K TQTGHS IRQ IMQGCN I LCATPGRLLDI I EKGK I SLVEVKYLVLDEADRMLDMGFGLDMKK TQTFHSLKQISEGCN I LCATPGRLLDVSRKEK IGLTKLRYLVLDEADRMLDMGF R E IE $S$ I NTGYT I REVLKGCNVLCATPGRLHDL IGRGKIGLSKVRYLVLDEADRMLDMGFE PEMRK TSVGYQ I RAVQKGCDVL I ATPGRLMDF INRGL IGLENVRF I I LDEADRMLDMGFE SE IRK TSFKYQNECITKGCHVL IATPGRLLDFVDRTF I T FDDTRF IVLDEADRMLDMGF SDSMRK VTTGYQAREVSKGAHLVVGTAGRLLDFIRKGYLSLAKVKYFILDEADRMLDMGF L P NMA VQVAYHLRQVAADCHLLVGTPGRLKDFLGKRK ISLANLKYLILDEADRMLDMG F L P E I KA * : * * $* * * *$

III

H. sapiens

G. gallus

R. nigromaculata

D. rerio

C. intestinalis

D. virilis

T. tubifex

H. magnipapillata

L I SCPGMPSKEQRQTLMFSATFPEEIQRLAAEFLKSNYLFVAVGQVGGACRDVQQTVLQV L I SYPEMPSKDRRQTLMFSATFPEEVQRLAGEFLKTDY I FLVIGNTCGACSDV Q Q I L QV LLKSPGMPSKEERQTLMFSATFPSSIQSLARE I LKPDYLFVVVGQVGGACSDVE Q LV IEV LVASPGMPSKEKRQTLMFSATYPEDIQRMAADFLKVDYIFLAVGVVGGACSDVEQTIVQV LVSLPGMPQKNNRHTLMFSATFPDE IQKLAHDFLREDFLFLTTVGRVGGASDVT QTVISV IMHHQTMRP - - EHQTLMF SATFPEE IQRMAGEFLK - NYVFVTIGVVGGACSDVQQTVYEV LANELGMPAKTERQTLMFSATFPEEVQQLAKELLN - DY I FVTVGRVGGANTD I E Q HVLQV I I NDFDMPPKEDRHTLMFSATFPTE IQNLAAEFLNN-YVYLTIGKVGGTHSD I T QC I MEV

H. sapiens
G. gallus
R. nigromaculata
D. rerio
C. intestinalis
D. virilis
T. tubifex
H. magnipapillata

GQFSKREKLVE I LRNIGDERTMVFVETKKKADF I ATFLCQEKISTTSIHGDRE QREREQA PRLSKRDKL I E ILQSTGGERTMVFVDTKKKADYLAAFLCQENLPSTSIHGDRE QRERE IA EESGKKDKLME I LQQ I GSERTMV FVKTKKKADF I ATFLCQEKVPSTS I HGDRE QREREMA DQY SKRDQLLELLRATGNERTMVFVETKRSADF IATFLCQEKISTTSIHGDRE QRE R K A EWKDKRSKLLELIADETKSRTLVFVETKRGADFLACVLCQEDFPTTSIHGDRLQQDREQA NKFNKR SKLME ILR - EGADGT IVFVETKRGADFLASFFSETEFPTTSIHGDR L QS QR E QA DQFNKREKLVS I LNSQGQQRTLVFVEQKRQADF IASYLSQSEFPTTSIHGDRE QRERE E EESAKRDKL I E I LDTEGTNRNLVFVQTKRLADFLASYLCQNGFHTTS I HGDR L Q Q Q RE EA

$$
\mathrm{V}
$$

$\mathrm{VI}$

H. sapiens
G. gallus
R. nigromaculata
D. rerio
C. intestinalis
D. virilis
T. tubifex
H. magnipapillata

LGDFRFGKCPVLVATSVAARGLDIENVQHVINFDLPSTIDEYVHRIGRTGRCGNT G LRDFRSGKCQI LVATSVASRGLDIENVQHV INFDLPNT I EDYVHR IGRTGRCGNTG LRDFRTGQCPVIVATSAAARGLDIENVSYVINFDVPDDIDEYVHRIGRTGRCGNTG LSDFRLGHCPVLVATSVAARGLDIEQVQHVVNFDMPSS I DEYVHR IGRTGRCGNTG LRDFKLAVCP I LVAT SVAARGLDI PKVEHV I NYDMPRE I DEYVHR IGRTGRCGNLG LRDFKTGTMKVL I AT SVASRGLDI KNVKHV INYDMPTNIDDYVHR IGRTGRVGNSG LRDFKNGTAP I LVAT SVAARGLDI PGVNHV INFDMPQS I DEYVHR IGRTGRC GNLG LAEFKAGTQHVL IATAVAARGLDIADVKQV INYDLPDE IEEY I HR IGRTGR I GNKG

Figure 1. Alignment of the RnVasa protein sequence with the other vasa proteins included in the phylogenetic tree (Fig. 2). The characteristic motifs of Vasa proteins are shaded gray. 


\section{RT-PCR}

RT-PCR was performed to study the RnVasa expression pattern in individual tissues. Results show that RnVasa is expressed in the heart, ovary, kidney, brain, and testis (Fig. 2). The level of expression, in descending order, is testis, kidney, ovary, brain, with faint expression in the heart. There is slight signal in other tissues such as spleen, muscle, pituitary and liver.

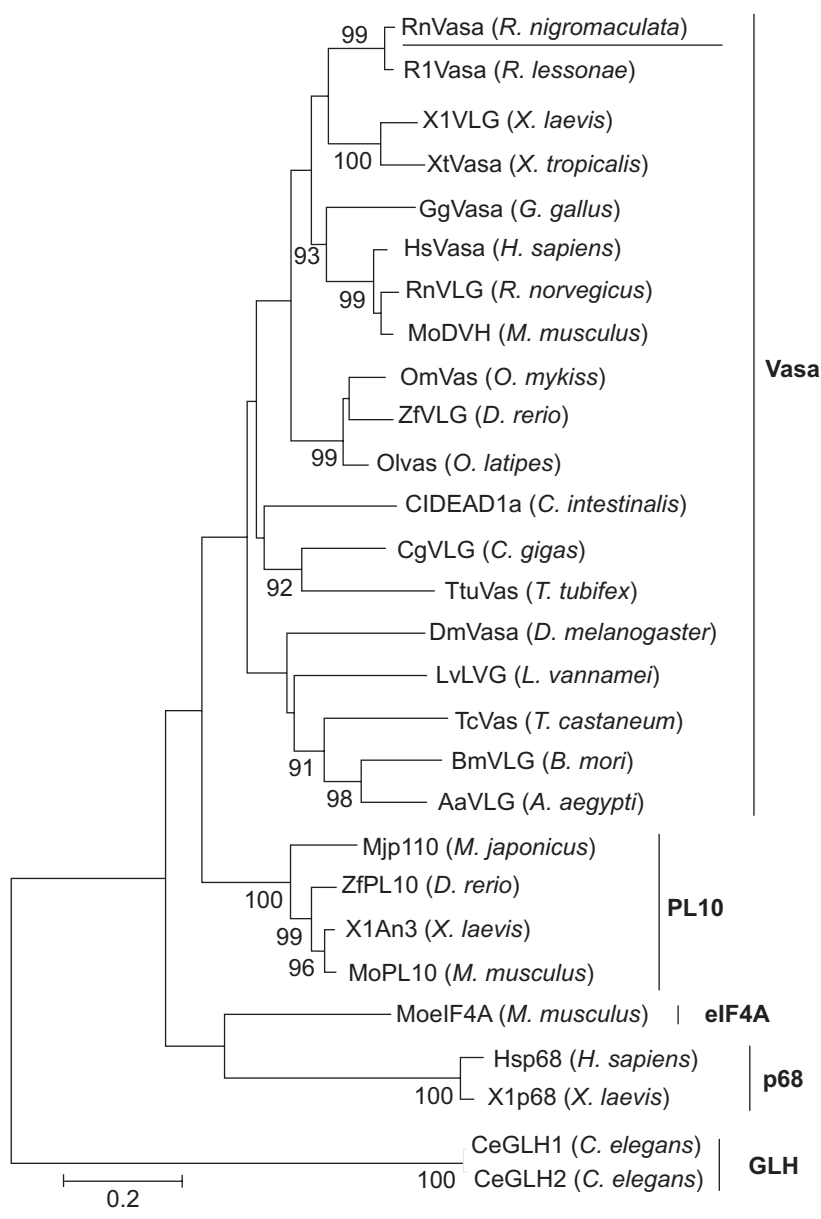

Figure 2. Phylogenetic trees of the deduced amino acid sequence of RnVasa and the complete amino acid sequences of 27 other DEAD-box proteins from different species. Numbers next to nodes are bootstrap values based on 1000 replicates, which indicate the reliability of branches in each tree. Branches with less than $90 \%$ support have been collapsed. Scale bars indicate number of substitutions per 100 amino acidresidues.

\section{DISCUSSION}

In this study, RnVasa, the full-length testis-derived cDNA of a putative Vasa from R. nigromaculata, was cloned, sequenced and its expression patterns were analyzed. The ORF of RnVasa was considerably shorter than the characterized complete coding sequences for Vasa in other species. Interestingly, however, the UTR at the 5' and 3' ends were similar in nucleotide length. This indicates that the UTRs of RnVasa may have similar functional roles to other characterized Vasa gene UTR regions (BARTFA \& ORBAN 2003). In RnVasa sequence, all nine known characteristic motifs of DEAD-box protein are present in their appropriate spacing. However, the I a 1 (PTRELINQ) motif shows conservative substitution in its amino acid sequence, Isoleucine for Alanine in PTRELAxQ motif (Fig. 1). Motif II (or Walker B motif) has the amino acids DEAD, for which the family is given the name. This motif, together with motif I (or Walker A motif), the Q-motif and motif VI, is required for ATP binding and hydrolysis (TANNer et al. 2003). Motifs Ia and Ib, III, IV and V have been characterized less well but may be involved in interaction with RNA and in intramolecular rearrangements necessary for remodeling activity.

Repeats in the N-terminal region (commonly arginineglycine-glycine (RGG) repeats) are also characteristic of many known Vasa proteins (Yoshizaki et al. 2000), It has been reported that this region is involved in the interaction with RNA (KILEDJIAN \& Dreyfuss 1992). However, no such repeats were found in RnVasa. Our finding is similar for Vasa genes of Danio rerio and Ciona intestinalis in which no duplicated regions have been found. So RGG is not necessary for RnVasa, the function of this region can be realized by the spatial interaction of different conserved motifs (CoRDin et al. 2006). There are four acidic amino acid residues in the last seven amino acid residues of RnVasa (Glutamate E and Aspartate D), that is in coincidence with the characteristic of Vasa protein sequences, which is identified by the ubiquity of several acidic amino acid in C-terminal of single strand DNA-binding protein (FABIous et al. 2004). The N-terminal of An3 knockout X. laevis has a normal ATPase activity than that of C-terminal knockout frog (GURURAJAN \& Weекs 1997), suggesting that the comparatively conservative C-terminal sequence in DEAD-box family proteins is important to the maintenance of protein function than that of $\mathrm{N}$ terminal.

The phylogenetic analysis supports that DEAD-box proteins assemble into different subgroups. It has been reported that similar DEAD-box proteins function similarly, i.e. p68, PL10 and related proteins within the same subgroup have similar biochemical properties (Rossler et al. 2001). Thus, it is very attractive to analyze structure, function and their correspondence of each subgroup and achieve some underlying rules.

IKENISHI \& TANAKA (2000) demonstrated that XVLG1 is expressed during early embryogenesis and might be involved in the differentiation not only of germline cells but also somatic cells. It is noteworthy that $X V L G 1$ was principally recognized in a juxtanuclear location of embryonic and adult germ cells and was detected transiently in the perinuclear region of somatic cells only at a certain period during development. After embryonic development, X. laevis DMRT1 was specifically ex- 
pressed in the primordial gonads at stage 52 . In this study, we showed that RnVasa was expressed in the gonad of testis and ovary adult frogs by RT-PCR (Fig. 3). This gives us a clue to track the origin, translocation and differentiation of primordial germ cells (PGCs) of $R$. nigromaculata. It is plausible that RnVasa protein also functions in translation as the RNA helicase not only in germline cells but also in somatic cells. Therefore, it is possible that RnVasa protein functions in the translation of unknown mRNA, each of which is essential to the specification of a certain cell type.

To date, RNA of Vasa and its homologs have mainly been studied in germline cells of larval or adult gonads as a molecular marker of germ-line cells. Accordingly, information about the spatio-temporal distribution of RNA in embryos is scarce for most of the animals, including Rana. It is important to know the distribution in this animal and to compare it to others if we are to understand to what extent the mechanism of germ cell formation is conserved among animal species. We will investigate it further. Lastly, the presence of RnVasa in the brain opens up the possibility of an autocrine control of gonadotropin of Vasa in this tissue, and, together with the presence of RnVasa in the heart and other tissues, additionally suggests a role for Vasa in functions other than reproduction.

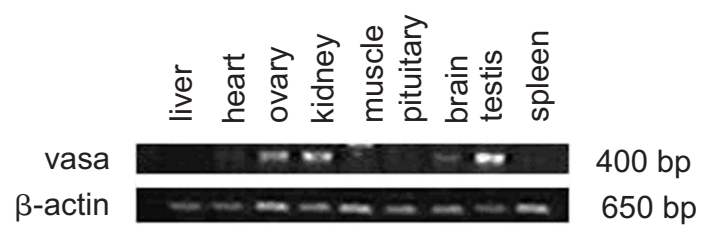

Figure 3. Tissue-specific expression of RnVasa in adult Rana nigromaculata. Total RNA was extracted from different adult tissues: liver, heart, ovary, kidney, muscle, pituitary, brain, testis and spleen. After the Dnase treatment, samples were subjected to RTPCR. $\beta$-actin was used as a positive control.

\section{ACKNOWLEDGEMENTS}

We would like to thank Pingping Zheng, Wen Chen for their kindly help in providing the testis cDNA library of $R$. nigromaculata. This research was supported by National Natural Science Foundation of China (30770296), the Natural and Science Key Project of Anhui Educational Department (KJ2007A022), and the Key Lab. of Biotic Environment and Ecology Safety in Anhui Province (2008).

\section{LITERATURE CITED}

Bartfai, R.\& L. Orban. 2003. The vasa Locus in Zebrafish: Multiple RGG Boxes from Duplications. DNA and Cell Biology 22 (1): 47-54.

Castrillon, D.H.; B.J. Quade; T.Y. Wang; C. Quigley \& C.P. Crum. 2000. The human VASA gene is specifically expressed in the germ cell lineage. Proceedings of the National Academy of Sciences (USA) 97 (17): 9585-9590.

Chang, C.; P. Dearden \& M. Akam. 2002. Germline development in the grasshopper Schistocerca gregaria: Vasa as a marker. Developmental Biology 252 (1): 100-118.

Chen, B.H. 1991. The Amphibian and Reptilian Fauna of Anhui. Hefei, Anhui Science \& Technology Publishing House, 408p.

Cordin, O.; J. Banroques; N.K. Tanner \& P. Linder. 2006. The DEAD-box protein family of RNA helicases. Gene 367 (15): 17-37.

Fabious, C.; S. Pouvreau; F.L. Roux \& A. Huvet. 2004. The oyster Vasa-like gene: a specific marker of the germline in Crassostrea gigas. Biochemical and Biophysical Research Communications 315 (4): 897-904.

FEI, L. 1999. China Wildlife Conservation Association. Atlas of Amphibians of China. Zhengzhou, Henan Science and Technology Publishing House, 432p.

Fujimura, M. \& K. Takamura. 2000. Characterization of an ascidian DEAD-box gene, Ci-DEAD1: specific expression in the germ cells and its mRNA localization in posteriormost blastomeres in early embryos. Development Genes and Evolution 210 (2): 64-72.

Frohman, M.A.; M.K. Dush \& G.R. Martin. 1988. Rapid production of full-length cDNAs from rare transcripts: amplification using a single gene-specific oligonucleotide primer. Proceedings of the National Academy of Sciences (USA) 85 (23): 8998-9002.

Geijsen, N.; M. Horoschak; K. Kim; J. Gribnau; K. Eggan \& G.Q. Daley. 2004. Derivation of embryonic germ cells and male gametes from embryonic stem cells. Nature 427 (6970): 148154.

GuO, X.; Y.T. GuI; A.F. TANG; L.H. Lu; X. GAO \& Z.M. CAI. 2007. Differential expression of VASA gene in ejaculated spermatozoa from normozoospermic men and patients with oligozoospermia. Asian Journal Andrology 9 (3): 339-344.

Gururajan, R. \& D.L. Weeks. 1997. An3 protein encoded by a localized maternal mRNA in Xenopus laevis is an ATPase with substratespecific RNA helicase activity. Biochimica et Biophysica Acta (BBA) - Gene Structure and Expression 1350 (2): 169-182.

HuAnG, Y. \& Z.R. Liu. 2002. The ATPase, RNA unwinding and RNA binding activities of recombinant p68 RNA helicase. Journal of Biological Chemistry 277 (15): 12810-12815.

Hubner, K.; G. Fuhrmann; L.K. Christenson; J. Kehler; R. Reinbold; R. De la Fuente; J. Wood; J.F. StraussiII; M. Boiani \& H.R. SCHOLER. 2003. Derivation of oocytes from mouse embryonic stem cells. Science 300 (5623): 1251-1256.

IKenISHI, K. \& T.S. TANAKa. 2000. Spatio-temporal expression of Xenopus vasa homolog, XVLG1, in oocytes and embryos: The presence of XVLG1 RNA in somatic cells as well as germline cells. Development, Growth and Differentiation 42 (2): 95-103. 
Johnstone, O. \& P. LASKo. 2004. Interaction with eIF5B is essential for Vasa function during development. Development 131: 4167-4178.

KiledjIAN, M. \& G. Dreyfuss. 1992. Primary structure and binding activity of the hnRNP U proteinÿbinding RNA through RGG box. The EMBO Journal 11 (77): 2655-2664.

Krovel, A.V.\& L.C. Olsen. 2004. Sexual dimorphic expression pattern of a splice variant of zebrafish vasa during gonadal development. Developmental Biology 271 (1): 190-197.

Kuznicki, K.A.; P.A. Smith; W.M. Leung-Chiu; A.O. Estevez; H.C. ScotT \& K.L. BENnETt. 2000. Combinatorial RNA interference indicates GLH-4 can compensate for GLH-1; these two P granule components are critical for fertility in C. elegans. Development 127 (13): 2907-2916.

Kumar, S.; K. Tamura \& M. Nei. 2004. An integrated software for molecular evolutionary genetics analysis and sequence alignment. Briefings in Bioinformatics 5 (2):150-163.

Lamm, G.M.; S.M. Nicol; F.V. Fuller-PaCe \& A.I. Lamond. 1996. p72: a human nuclear DEAD box protein highly related to p68. Nucleic Acids Research 24 (19): 3739-3747.

Liang, L.; W. Diehl-Jones \& P. Lasko. 1994. Localization of Vasa protein to the Drosophila pole plasm is independent of its RNA-binding and helicase activities. Development 120 (5): 1201-1211.

Mochizuki, K.; C. Nishiyama-Fujisawa \& T. Fujisawa. 2001. Universal occurrence of the Vasa-related genes among metazoans and their germline expression in Hydra. Development Genes and Evolution 211 (6): 299-308.

NAKAO, H. 1999. Isolation and characterization of a Bombyx Vasalike gene. Development Genes and Evolution 209 (5): 312 316.

Rossler, O.G.; A. Straka \& H. Stahl. 2001. Rearrangement of structured RNA via branch migration structures catalysed by the highly related DEAD-box proteins p68 and p72.
Nucleic Acids Research 29 (10): 2088-2096.

Sagawa, K.; H. Yamagata \& Y. Shiga. 2005. Exploring embryonic germline development in the water flea, Daphnia magna, by zinc-finger-containing VASA as a marker. Gene Expression Patterns 5 (5): 669-678.

SAitou, N. \& M. NeI. 1987. The neighbor-joining method: a new method for reconstructing phylogenetic trees. Molecular Biology and Evolution 4 (4): 406-425.

Schmucker, D.; G. Vorbruggen; P. Yeghiayan; H.Q. Fan; H. Jackle \& U. GAUl. 2000. The Drosophila gene abstrakt, required for visual system development, encodes a putative RNA helicase of the DEAD box protein family. Mechanisms of Development 91 (1-2): 189-196.

Tanner, N.K.; O. Cordin; J. Banroques; M. Doere \& P. Linder. 2003. The Q motif. A newly identified motif in DEAD box helicases may regulate ATP binding and hydrolysis. Molecular Cell 11 (1): 27-138.

Tsunekawa, N.; M. Naito; Y. SAKai; T. Nishida \& T. Noce. 2000. Isolation of chicken Vasa homolog gene and tracing the origin of primordial germ cells. Development 127 (12): 2741-2750.

Tanaka, S.S.; Y. Toyooka; R. Akasu; Y. Katoh-Fukui; Y. Nakahara; R. Suzuki; M. Yokoyama \& T. Noce. 2000. The mouse homolog of Drosophila Vasa is required for the development of male germ cells. Genes and Development 14 (7): 841-853.

Thompson, J.D.; D.G. Higgins \& T.J. Gibson. 1994. Clustal W: improving the sensitivity of progressive multiple sequence alignment through sequence weighting, position-specific gap penalties and weight matrix choice. Nucleic Acids Research 22 (22): 4673-4680.

Yoshizaki, G.; Y. Takeuchi; S. Sakatani \& T. Takeuchi. 2000. Germ cell-specific expression of green fluorescent protein in transgenic rainbow trout under control of the rainbow trout vasa-like gene promoter. International Journal of Developmental Biology 44: 323-326.

Submitted: 29.IX.2008; Accepted: 08.VI.2009.

Editorial responsability: Marcio R. Pie 